\title{
On the Legal Problems in the Establishment of Religious Organizations in China
}

\author{
Li Yan \\ Faculty of Humanities \\ China University of Political Science and Law \\ Beijing, China 100088
}

\begin{abstract}
China's religious groups since the founding of the government has been strictly controlled by the special social groups. The government limits the religious community to government-approved spaces and subjects through administrative legislation. At present, there are serious problems in the legislation of religious organizations, such as the strict conditions of establishment, the complicated examination and approval procedures, the policy of religious community governance and the lack of approval of the establishment of religious groups, which limits the organic development of legitimate religious groups. Religious groups offer the possibility of secrecy.
\end{abstract}

Keywords—societies; religious groups; government; legislation

\section{INTRODUCTION}

Religious groups as a typical non-profit community, is a voluntary organization of Chinese citizens, in order to achieve the common wishes of religious believers, according to their law, rules, regulations to carry out religious activities of social organizations. Religious associations represent the interests of specific masses and are the bridge and link between the party and the government and the masses. Perfecting the relevant laws of the religious community will help to further manage the religious community in accordance with the law and play a positive role in the cause of the modernization of religious communities. After the founding of the People's Republic of China, the State Council promulgated the Interim Measures on the Registration of Social Organizations in 1950, which stipulated that the administrative departments should examine and approve the administrative departments in charge and clean up and reorganize old social associations including religious groups. After 1980, with the rapid economic and social development, a large number of religious communities don't have the approval of the government without authorization. In view of the surge in the number of religious associations and the registration of chaos, the Chinese government has promulgated the Regulations on the Administration of Social Organizations (1989) and the Regulations on Religious Affairs (2004) to regulate the establishment of religious communities. After many years of legislative practice, the current religious groups in the establishment of the process there are the following legal issues:

\section{THE ESTABLISHMENT OF RELIGIOUS GROUPS STRICT CONDITIONS}

In accordance with the Regulations on the Registration of Social Organizations and the Measures for the Administration of the Registration of Religious Social Organizations, the following conditions shall apply: (1) with the consent of the competent business unit; (2) there are 50 or more individual members or 30 More than 50 members; (3) a standardized name and the corresponding organization; (4) a fixed residence; (5) a business with the business; (3) a number of members of the unit; (6) there are legitimate assets and funding sources, the national social groups should have more than 100,000 yuan of activities funds, local social groups have more than 30,000 yuan of funds for activities; (7) have the ability to bear civil liability; (8) have a testable, consistent with the history of our existing religion, does not violate the constitution of the classics; (9) the organization of the organization has a wide range of representative.

Legal Provisions on the Establishment of Religious Organizations There are the following problems in practical operation:

- The conditions for the establishment of the religious community to apply for preparation before the need to obtain a fixed residence, the preparation of the application must provide proof of ownership or lease contract and other supporting documents, may cause religious associations in order to Ready to spend a large number of housing to buy or lease costs, squeeze community funds. If the religious community is not approved to set up the cost cannot be recovered, the establishment of the process of sunk costs.

- The identity of the sponsor of the religious society and the identity of the person in charge need to be dependent on the government's approval. In 1991, the Ministry of Civil Affairs pointed out that it was necessary to pay attention to whether the head of the society adhered to the four basic principles in order to ensure that the political direction of the society did not deviate. In 1998, the Ministry of Civil Affairs "on the rectification of community certification and renewal of the certificate of work notice" stipulates: "the person in charge of the community should be through the unit of the personnel department and business unit after the 
audit, and then by the association according to its constitutional procedures Election." The provisions of the requirements of the community responsible person selection procedures not only need to prove that the unit, but also need to agree with the unit personnel department, if the person in charge does not have the unit, the establishment of the community may also be shelved.

- $\quad$ There are testimonies, in line with the history of our existing religion, does not violate the constitution of the body of the classics, doctrines and teachings", only one, the government can be rejected under the five religions of other traditional religions and emerging religion. Judging from the approval of religious communities in practice, the government encourages the establishment of traditional five religious communities according to law, restricting the establishment of folk traditional religious communities and emerging religious communities.

- The law does not specify the widely representative judgment criteria that religious society members should have, and the government's discretion.

The establishment of religious groups' harsh conditions, reflecting the government to restrict the development of religious communities, government-centrism as the starting point to maintain stability as the goal of the political philosophy. Religious associations, after filtering the rules of the government set up by the government, have avoided the establishment of religious groups that are inconsistent with the government's goals, but have also led to the existence of secret activities in a large number of religious communities and increased the possibility of social conflict.

\section{THE RELIGIOUS GROUP APPROVAL AND REGISTRATION Procedures ARE CUMBERSOME}

Religious groups as a form of social organization, like other social organizations, pass a certain form of social recognition and legal protection. Approval and registration is the basic form of the state to determine the legitimacy of religious groups, but also religious groups to obtain social recognition of the legal channels. The procedure for applying for the establishment of a religious group includes a professional audit procedure (ie, whether the business unit examines the consent of the religious community) and the government approval process. The establishment of a religious group shall be entered into the registration procedure after the consent of the local religious affairs department, including the dual procedures of the civil affairs department registration procedure and the filing procedure of the religious affairs department.

There are two legal issues at this stage: First, the law does not specify which documents the religious community should submit to the business manager and the response period of the business unit, so that the trial procedure of the religious community is vague. This kind of fuzzy legislation causes the business unit to be reluctant to bear the preliminary responsibility of the establishment of the society outside the scope of its own functions, and delay the preliminary examination by delaying and resting.

Second, the multi-sectoral administrative examination and approval system of religious groups is likely to lead to the examination of standard differences and long management problems. The unity of religious groups shall be registered by the civil affairs departments at all levels and shall be examined and approved by the civil affairs departments and the religious departments. The double examination and approval system establishes the double insurance for the establishment of the religious community, but the inconsistent examination criteria of the examination and approval department and how to exercise the discretion in the examination process are the longstanding problems in the approval of the religious community. Double approval in the effective control of the number of religious communities at the same time and hidden management of the community into a long management state, so that a large number of unregistered civil religious organizations. [1]

\section{THE BASIS OF GOVERnMENT MANAGEMENT OF RELigious COMMUNiTIES SHOW POLICY TENDENCIES}

China's religious community management to implement the government management model, the survival and development of religious communities are determined by the government. This model is the product of the planned economy model and the highly centralized administrative mode and the influence of the government's omnipotentism in the feudal society after 30 years of founding. [2] In accordance with the Regulations on the Administration of Social Organizations and the Regulations on the Administration of Religious Affairs, the government has established a system of reporting, annual inspection and administrative penalties for religious activities. But through the issuance of guidance, advice and other policy of administrative decisions, so that religious societies of legal governance cast a random and strong administrative management. The management of the religious community in the process of policy management is mainly reflected in:

\section{A. Clean up the Rectification Policy}

Since the founding of the PRC, the government has carried out large-scale rectification and rectification of religious communities from time to time. The first clean-up and rectification was carried out in the $1950 \mathrm{~s}$, after the promulgation of the Interim Measures for the Registration of Societies, to clean up and dissolve the religious societies such as the various societies left over from the old society. In the 1980s, the change of the national economic policy led to the rapid increase of the religious community. In 1989, the State Council cleared and rectified the established religious community without approval in accordance with the Regulations on the Registration of Social Organizations. In 1997, the General Office of the State Council issued the Circular on Forwarding the Opinions of the Ministry of Civil Affairs on the Rectification and Rectification of Social Organizations, and the reorganization and reorganization of the community was carried out nationwide. No new religious associations were examined and approved during the rectification and rectification. Since then, every few years, the 
government paid attention to clean up the consolidation of religious communities many times in the country through administrative. Clean up and rectify as an administrative act is a manifestation of political orders and decisions. Such an intention to control and clean up a regulated religious community through administrative orders rather than by law is an impact on the rule of law governing religious societies. In practice, the administrative authority of the administrative costs is limited, cannot achieve tight control of religious communities. Religious associations in the actual social life are not strictly controlled, but often in the laissez-faire development of the state.

\section{B. The Government Requires Religious Groups to Formulate Policies of Religious Associations in Accordance with the Charter Provided by the Government}

Religious groups implement the constitution as the core of the internal management system. The constitution of the religious group is the consensus of its members on the concept of beliefs and beliefs, which embodies the principle of autonomy of meaning of the society. The legislative and administrative organs shall not make legal judgment and political judgment on the contents of the articles of association. In 1998, the Ministry of Civil Affairs formulated the Model Textbook of the Constitution of Social Organizations, which required the civil affairs bureaus at all levels to scrutinize the articles of association of religious communities with reference to the model text. The constitution of a religious group must be formulated in accordance with the model text and submitted to the agency registration authority for approval. The model of the association's statutes is forcibly promoted and has a wide range of practical effects by virtue of the power of the administrative body of the Ministry of Civil Affairs. Once the draft constitution of the religious association is in conflict with the model, it must be amended. Otherwise, the government will not approve the establishment of religious groups. Religious charter as a religious group of voluntary and autonomy of the text reflects the religious group internal affairs, should be determined by the religious groups. The government modeled the statutes of the religious groups, which reflected the government's infiltration of management power into the religious groups, and the expansion of the autonomy of religious groups while expanding the power of government, and this extension of power will inevitably lead to the lack of autonomy in our religious groups, The dependence of religious groups on the government has hindered the modernization of religious groups.

\section{DO NOT APPROVE THE ESTABLISHMENT OF RELIGIOUS GROUPS, THE LEGAL REASONS ARE BROAD}

The main reasons for the non-approval of the religious associations by the registration authority are as follows: First, there is evidence of the purpose of the religious community that has been prepared for application. The scope of business does not conform to the provisions of Article 4 of the Regulations on the Registration of Social Organizations, that is, social organizations must abide by the Constitution Laws and regulations and national policies shall not oppose the basic principles set forth in the Constitution and shall not endanger the unity of the state, safety and national unity without prejudice to the national interests, the public interests of the society and the legitimate rights and interests of other organizations and citizens and shall not violate the social morality, Social organizations are not allowed to engage in for-profit business activities. Second, the same administrative region has the same business or similar social groups, there is no need to set up; Third, the sponsor, the person in charge is or has been deprived of political rights of criminal penalties, or do not have full civil action The fourth, in the preparation of the fraud; fifth, there are laws and administrative regulations prohibit other circumstances. Here, explore a few points:

\section{A. Whether Religious Communities Must Comply with the Policy}

Article 6 of the General Principles of Civil Law stipulates that "civil activities must comply with the law and the law does not stipulate that the state policy should be observed." The compliance of the state policy must be the case where the law does not stipulate. The definition and scope of national policies are not clearly defined at present. If the documents issued by the state organs are collectively referred to as national policies, some policies are not systematically publicized, published and publicized, and some policies are even contrary to the law of the expedient policy; if the above policy is contrary to the rule of law The Priority in policy compliance means that our country is still pushing religion in accordance with our policies.

\section{B. How to Determine in the Same Administrative Region has the Same Scope of Business or Similar Religious Communities}

In 1989, the Ministry of Civil Affairs pointed out in the Notice on the Relevant Issues Concerning the Regulations on the Registration of Social Organizations. The same scope of business means that the name, purpose, nature and tasks of the society are the same or basically the same; similar to the name of the community. Different, staff composition is also different, but the actual business activities belong to the same business areas. This legal provision is mainly to avoid the establishment of too many communities, the heavy economic burden of members and other social adverse effects. Religious groups are different from the general social groups, with strong spiritual dependence and identity. Even if the same religion belongs to the same religion, the difference in the clerical dependency of the believers is due to the difference in the clergy of the religious group, that is, the different groups of the same religion will be irreplaceable by the choice of religious groups for the choice of clerics. The mere incorporation of believers into designated religious groups in accordance with the same religion may harm the believer's sentiment and lead to unnecessary disputes. As for the repeated establishment of religious groups is the meaning of autonomy and voluntary choice of members, the increase in the cost of choice by their own commitment, if the government to use the legal system to reduce the freedom of religious freedom of the people in order to achieve the purpose of easy management and control, The constitutional goal of freedom of association is diametrically opposed. The reason for this non-approval is mainly to reduce the competition of religious communities, to control the number of religious communities and to restrict the establishment of branches of 
religious communities, to prevent the religious community is too large to lead difficult to manage and control. The necessity of the establishment of a religious community should be paid by the people who have the need for religious association.

\section{About the Person in Charge of the Qualifications}

Since the act of association is based on the contractual act between the promoters and the person in charge of the society is acting on behalf of or acting on behalf of the civil society, these acts require the perpetrator to have full civil capacity and Public law on the behavior, so the prohibition of minors, mental patients as the sponsor of the community, the person in charge of civil law in line with the provisions. [3] If a person has been deprived of political rights of criminal penalties, the permanent loss of the sponsor or the person in charge of the qualifications, no doubt implicitly extended its legal sanctions. As a result, the conditions for the imposition of sanctions on the origin of a religious society or the person in charge of a person in charge of personal law should be further discussed.

\section{CONCLUSION}

Religious societies harsh set up conditions and approval procedures, as if to the religious association to wear a "magic spell", all to the government as "Zhanzhang." Religious associations that can be registered and established are basically religious organizations tamed by "politics". And the limited administrative costs of the government, and lead to more religious association because of failure to meet the political legitimacy, the legitimacy of the legal system cannot be registered and embarrassed: the legal association of these religions is illegal, not legitimate But in social life but it is open to the activities of its participation in the activities and activities of the content of a certain geographical or a certain group of recognition, with its social legitimacy, and such religious association is not because of its illegal and legal Any cut. This embarrassing and contradictory situation, no doubt for a small number of social extremist religious association provides a hidden and survival of the soil. Thus, when the government tightens religious policy, these illegal extremist religious associations are suppressed and stopped by numerous religious associations that have not been approved or registered, and once the policy is tightened, these illegal and extreme religious associations are Numerous unapproved or registered religious associations surfaced, semi-public, and openly religious activities. Therefore, in the face of increasing religious groups and religious activities in the name of religion, how to pass the law rather than the political governance of religious communities, the appropriate path is to give religious autonomy and the government of religious community management of the normalization.

\section{REFERENCES}

[1] Yu Keping. On China's civil society in a number of questions from the high C, Yuan Ruijun editor of "China's civil society development blue book" [M]. Beijing: Peking University Press .2008: 19.

[2] Wu Yuzhang. Civil society legal thinking [M]. Beijing: Social Science Literature Publishing House .2010: 52-53.

[3] Su Li, Ge Yunsong, Zhang Shouwen, Gao Bingzhong. Regulation and development [M]. Hangzhou: Zhejiang People's Publishing House .1999: 48. 